\title{
Manajemen Pembangunan Fasilitas Rekreasi Pada Kolam Retensi Muktiharjo Kidul, Semarang
}

\author{
Recreational Facility Building Management on Muktiharjo Kidul \\ Retention Pond, Semarang
}

\author{
Addini Ayu Tresiana ${ }^{1}$ \\ Universitas Diponegoro, Semarang, Indonesia \\ Djoko Suwandono² \\ Universitas Diponegoro, Semarang, Indonesia
}

\begin{abstract}
Abstrak: Kolam retensi yang saat ini telah dibangun pada Kelurahan Muktiharjo Kidul, Semarang seringkali dikunjungi masyarakat untuk sekedar mengisi waktu luang dengan bercengkrama disekitar kolam, meskipun tidak terdapat fasilitas penunjang untuk pengunjung. Perencanaan fasilitas rekreasi pada kolam retensi perlu dilakukan supaya pengembangan aktivitas dapat dikelola dengan baik sehingga tidak menggangu kinerja kolam retensi dalam mengatasi banjir. Rencana tersebut berupa rancangan fasilitas rekreasi yang akan dibangun dari segi fisik serta pembiayaan, sebagai rekomendasi rencana pembangunan bagi pemerintah. Metode yang digunakan adalah penelitian kuantitatif dalam analisis perhitungan pembiayaan pembangunan dan kelayakan ekonomi dengan pendekatan kualitatif karena observasi dilakukan secara naturalistik. Pengamatan pada wilayah studi dilakukan hanya dengan mengamati kondisi lingkungan sekitar yang tidak terkuantifikasi. Hasil akhir dari penelitian adalah rekomendasi yang ditujukan untuk pemerintah dalam perencanaan kolam retensi khususnya manajemen pengembangan untuk membangun fasilitas rekreasi. Konsep manajemen pembangunan yang disusun berupa analisis kelayakan ekonomi, perhitungan pembiayaan pembangunan dan bentuk kerjasama pemerintah-swasta yang sesuai pada fasilitas rekreasi.
\end{abstract}

Kata kunci: kolam retensi; fasilitas rekreasi; manajemen pengembangan; kelayakan ekonomi; kerjasama pemerintah-swasta

\begin{abstract}
Retention pond that currently have been built in Muktiharjo Kidul, Semarang often visited by community to enjoy the spare time with chatting around the pond, although there is no supporting facilities for visitors. Planning of recreational facilities on retention pond needs to be done so that development activities can be managed properly and not interfere with performance to controlling flood on retention pond. The plan in the form of draft recreation facilities to be constructed in terms of physical as well as financing, as a recommendation for the government development plan. The method used is the quantitative research in the analysis of the calculation of the financing of development and the qualitative approach with economic feasibility because naturalistic observation is carried out. The final results of the research are recommendations addressed to Governments in the planning of management development in particular the retention pond to build recreational facilities. Construction management concept drawn up in the form of an economic feasibility analysis, calculation of the financing of the construction and shape of the public private partnership that fits on the recreational facilities.
\end{abstract}

Keywords: retention pond; recreational facilities; economic feasibility; development management; public private partnership

\footnotetext{
${ }^{1}$ Korespondensi Penulis: Universitas Diponegoro, Semarang, Indonesia Email: addintresiana@gmail.com

2 Korespondensi Penulis: Universitas Diponegoro, Semarang, Indonesia Email: dj.suwandono@gmail.com
} 
Pendahuluan

Pada tahun 2014 Pemerintah Kota Semarang melakukan pelaksanaan rencana pembangunan kolam retensi yang berlokasi di Kelurahan Muktiharjo Kidul, Kecamatan Pedurungan, dengan tujuan mengatasi permasalahan banjir pada wilayah sekitar. Lahan untuk pembangunan kolam retensi tersebut merupakan lahan pemerintah yang sebelumnya digunakan sebagai tambak yang dikelola oleh warga. Jumlah tambak yang dibebaskan pada awal pembangunan kolam retensi adalah sebanyak 42 petak, yang setiap tambak dihargai sebesar Rp 5.000.000,00.

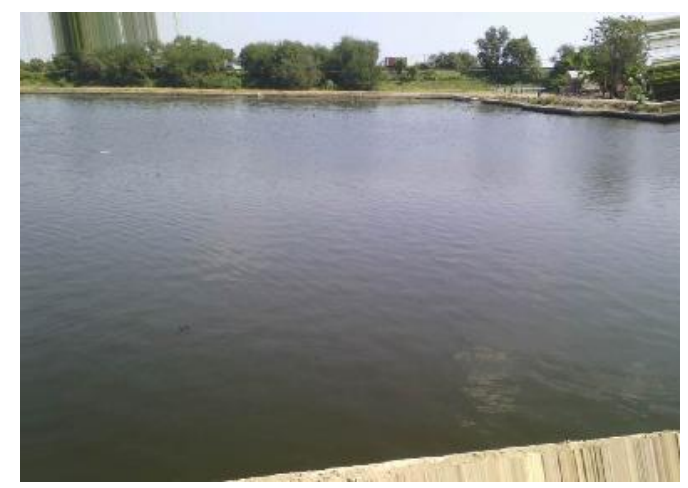

Sumber: Dokumentasi peneliti, 2015.

Gambar 1. Kolam Retensi Muktiharjo Kidul

Kolam retensi yang saat ini telah tersedia sebagai bangunan penampung air hujan dan pengendali banjir di lingkungan Kelurahan Muktiharjo Kidul seringkali dikunjungi masyarakat untuk sekedar mengisi waktu luang dengan bercengkrama disekitar kolam, meskipun tidak terdapat fasilitas penunjang untuk pengunjung. Mempertimbangkan hal tersebut, kolam retensi memiliki potensi untuk dikembangkan sebagai fasilitas rekreasi dengan atraksinya berupa kolam yang dapat dimanfaatkan sebagai lokasi rekreasi air. Pengembangan tersebut juga merupakan tindakan preventif yang dilakukan untuk menghindari kemungkinan adanya kegiatan-kegiatan yang kurang bermanfaat yang dapat dilakukan oleh masyarakat di sekitar lokasi kolam. Minat masyarakat tentang rencana pembangunan fasilitas rekreasi pada kolam retensi cukup tinggi karena saat ini pada Kelurahan Muktiharjo Kidul dan sekitarnya belum terdapat fasilitas rekreasi air.

Perencanaan fasilitas rekreasi pada kolam retensi perlu dilakukan supaya pengembangan aktivitas dapat dikelola dengan baik sehingga tidak menggangu kinerja kolam retensi dalam mengatasi banjir. Rencana tersebut berupa rancangan fasilitas rekreasi yang akan dibangun dari segi fisik serta pembiayaan, sebagai rekomendasi rencana pembangunan bagi pemerintah. Biaya-biaya yang akan dikeluarkan pemerintah maupun swasta dalam pembangunan didapat dari rencana fasilitas rekreasi yang sebelumnya telah dirumuskan, diantaranya seperti biaya pekerjaan jalan dan pengadaan kios pada fasilitas rekreasi. Keterbatasan dana yang dimiliki oleh pemerintah dalam pembangunan infrastruktur perkotaan mendorong perlunya dilakukan kerjasama antara pemerintah dan swasta dalam hal manajemen pembangunan. Jenis kerjasama yang akan dilakukan dipilih berdasarkan beberapa pertimbangan, salah satunya adalah pihak akhir yang akan mengelola fasilitas rekreasi (pemerintah atau swasta). Adanya dua kegiatan dalam satu lokasi berupa kolam retensi dan fasilitas rekreasi perlu dikelola secara lebih dalam supaya tidak saling memberikan pengaruh yang negatif.

Berdasarkan hal tersebut perlu diketahui konsep manajemen pembangunan yang dapat dilakukan dengan sistem kerjasama pemerintah-swasta sehingga nantinya dapat diterapkan saat pembangunan fasilitas rekreasi. Konsep manajemen pembangunan yang disusun berupaperhitungan pembiayaan pembangunan, analisis kelayakan ekonomi dan bentuk kerjasama pemerintah-swasta yang sesuai pada fasilitas rekreasi. Pembiayaan pembangunan dilakukan dengan mengidentifikasi biaya-biaya yang dibutuhkan dalam pembangunan fasilitas rekreasi dan prakiraan biaya yang didapat saat fasilitas rekreasi telah beroperasi. Kelayakan ekonomi dilihat 


\section{Metode Penelitian}

\section{Gambaran Umum}

dari dua aspek yaitu aspek cost dan benefit, dimana penentuannya menggunakan tiga kriteria yaitu NPV, BCR dan IRR. Jenis kerjasama yang akan digunakan dalam membangun faislitas rekreasi adalah BOT, yaitu kerjasama antara pemerintah dengan swasta yang pada masa kontrak, aset berupa fasilitas rekreasi kembali ke pemerintah.

Metode yang digunakan dalam perencanaan fasilitas rekreasi kolam retensi di Kelurahan Muktiharjo Kidul adalah kuantitatif dan kualitatif. Fokus dari penelitian kuantitatif adalah survey atau eksperimen dengan mereflesikan asumsi pospositivisme. Sedangkan metode kualitatif, digunakan untuk melakukan observasi secara naturalistik, sehingga nantinya didapatkan gambaran untuk menyusun perancangan. Alasan pemilihan metode ini adalah untuk mengetahui kondisi dan karakteristik dari studi yang dilakukan dengan melihat data-data yang selanjutnya dianalisis menggunakan analisis statistik untuk menguji hipotesis yang dilakukan. Pengolahan data tersebut dilakukan dengan menggunakan statistik deskrptif yang kemudian hasil dari pengolahan tersebut digambarkan tanpa bermaksud membuat kesimpulan yang berlaku untuk umum atau generalisasi.

Dalam melakukan pengumpulan data yang diperlukan, terdapat dua jenis data yaitu data primer dan data sekunder. Teknik pengumpulan data primermerupakan pengumpulan data yang dilakukan secara langsung oleh pengumpul data dengan menggunakan teknik-teknik pengumpulan seperti wawancara kepada pihak yang terkait, observasi dan kuesioner kepada masyarakat untuk melihat kondisi secara langsung.

Teknik sampling yang digunakan dalam penelitian dan perencanaan ini menggunakan teknik sampling purposive. Peneknan metode penelitian purposive ini adalah pada karakter anggota sampel yang karena pertimbangan mendalam dianggap/ diyakini oleh peneliti akan benar-benar mewakili karakter populasi/ subpopulasi (Yunus, 2010; 302). Teknik sampling purposive ini difokuskan pada pertimbangan untuk pemilihan populasi yang akan disurvei. Pertimbangan yang ditentukan harus dapat menjelaskan bahwa keterwakilan dari populasi tersebut sudah tepat dan layak dijadikan sebagai sampel. Sampling dilakukan pada ahli-ahli perencana yang mengetahui tentang kolam retensi, dinas-dinas yang terkait dalam pembangunan kolam retensi, masyarakat dan Kelurahan Muktiharjo Kidul yang menjadi target perencanaan fasilitas rekreasi pada kolam retensi tersebut.

Pembangunan kolam retensi menurut Rencana Kerja Pembangunan Daerah (RKPD) Kota Semarang tahun 2014 berada di Kelurahan Muktiharjo Kidul yang masuk dalam wilayah Kecamatan Pedurungan karena merupakan daerah banjir. Kelurahan Muktiharjo Kidul berbatasan dengan Kecamatan Genuk di bagian Utara dan Kecamatan Gayamsari pada bagian Barat sedangkan pada bagian Timur dan Selatan berbatasan dengan kelurahan lain di Kecamatan Pedurungan seperti pada peta dibawah. Berdasarkan batas tersebut, dapat diketahui bahwa lokasi Kelurahan Muktiharjo Kidul terletak paling Utara di wilayah Kecamatan Pedurungan.Secara geografis, Kelurahan Muktiharjo Kidul berada pada daratan rendah dengan kondisi fisik kelerengan bernilai 0-8\%. Berkaitan dengan wilayahnya yang datar, kedekatan jarak dengan pusat kota, serta jenis tanah yang sesuai untuk dibangun, saat ini lahan di Kelurahan Muktiharjo Kidul sudah dipenuhi oleh bangunan-bangunan perumahan maupun sarana prasarana. Pihak yang melakukan pembangunan tersebut beragam, mulai dari masyarakat secara pribadi maupun swadaya, pemerintah, serta swasta yang memiliki kepentingan tertentu.

Banjir paling parah di Kelurahan Muktiharjo Kidul pernah terjadi tahun 2012 pada wilayah antara RW 12 dan 13 dengan ketinggian mencapai $2 \mathrm{~m}$. Akses jalan terputus dan sebagian rumah warga terendam banjir. Bantuan yang didapat warga dari kelurahan saat terjadi banjir biasanya berupa bantuan makanan (mi instan) dan tenda darurat namun beberapa warga memilih untuk sementara tinggal di rumah kerabat terdekat. Pada tahun 2015, kejadian banjir relatif berkurang karena jarang terjadi hujan. Apabila hujan, genangan yang masih sering terjadi pada wilayah permukiman ketinggiannya adalah sekitar $30-40 \mathrm{~cm}$. 


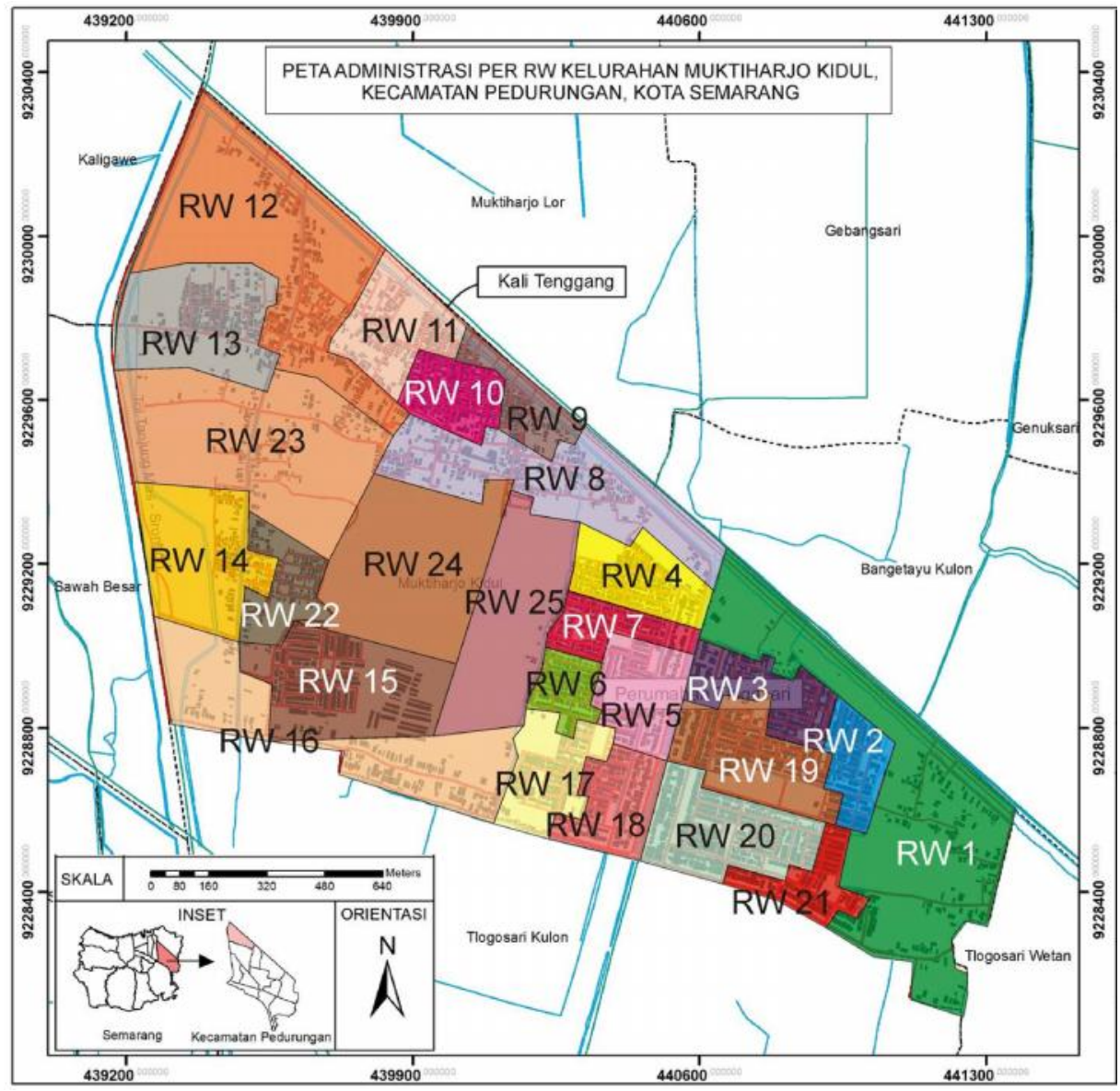

Sumber: Bappede Kota Semarang, 2011.

\section{Gambar 2. Peta Administrasi per RW Kelurahan Muktiharjo Kidul}

Lokasi pembangunan kolam retensi yang terdapat di RW 12 dan 13 Kelurahan Muktiharjo Kidul, Kecamatan Pedurungan dibangun pada lahan milik pemerintah dengan luas $5,8 \mathrm{Ha}$. Lahan tersebut terletak pada bagian utara Kelurahan Muktiharjo Kidul. Lokasi yang digunakan tersebut berada pada pertemuan saluran drainase primer dan sekunder. Pembangunan kolam retensi Muktiharjo Kidul memiliki beberapa komponen yang digunakan dalam mengoperasikannya. Komponenkomponen yang digunakan atau yang dibangun pada kolam retensi tersebut adalah kolam tampung, pompa, pintu air, saringan sampah, tanggul keliling, mercu pelimpah, rumah penjaga, dan pagar pengaman.

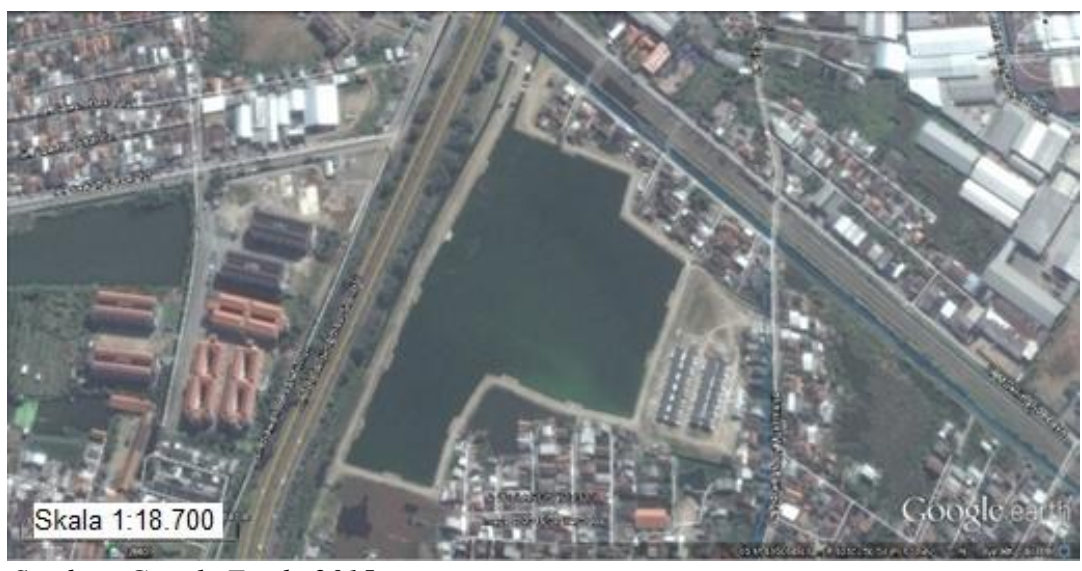

Sumber: Google Earth, 2015.

Gambar 3. Citra Lokasi Kolam Retensi Muktiharjo Kidul 
Pembangunan kolam retensi direncakan dengan beberapa data yang dijadikan untuk pembangunan kolam retensi tersebut. Pembangunan kolam retensi direncanakan dengan luas kolam retensi sebesar $58.000 \mathrm{~m}^{2}$ dengan kedalaman 3,5 $\mathrm{m}$. rencana kedalaman yang digunakan dengan kedalaman air maksimal yaitu $3 \mathrm{~m}$ dan kedalaman air normal $2 \mathrm{~m}$. sedangkan sisa dari kedalaman tersebut digunakan untuk cadangan untuk sedimen. Volume banjir yang terjadi pada kawasan tersebut adalah 235.547.200 liter. Dalam rencana tersebut dibangun Volume total dari Kolam retensi yaitu $203.000 \mathrm{~m}^{3}$ dan volume efektif pengendali banjir adalah $174.000 \mathrm{~m}^{3}$.

Adanya kawasan permukiman disekitar menyebabkan timbulnya kebutuhan fasilitas rekreasi bagi masyarakat. Saat ini, tidak ditemui fasilitas rekreasi di wilayah Kelurahan Muktiharjo Kidul. Pada kawasan sekitarnya terdapat Taman Virgin yang berada di Bumi Tlogosari, Kelurahan Tlogosari Kulon. Atraksi pada fasilitas rekreasi tersebut berupa taman bermain, dan lapangan yang dapat digunakan untuk olahraga seperti futsal serta badminton maupun digunakan untuk berjualan. Pembangunan fasilitas rekreasi pada kolam retensi belum mulai dilaksanakan walaupun sudah terdapat rencana yang disusun oleh dinas terkait. Rencana pembangunan fasilitas rekreasi pada kolam retensi memiliki keunikan karena menawarkan wisata air yang belum ada di wilayah sekitar. Keberadaan fasilitas rekreasi pada kolam retensi diharapkan mampu memenuhi kebutuhan masyarakat khususnya dalam hal hiburan yang berkaitan dengan alam. Pengelolaan Taman Virgin yang sudah cukup baik juga selanjutnya dapat diterapkan pada fasilitas rekreasi yang akan dibangun pada kolam retensi Muktiharjo Kidul.

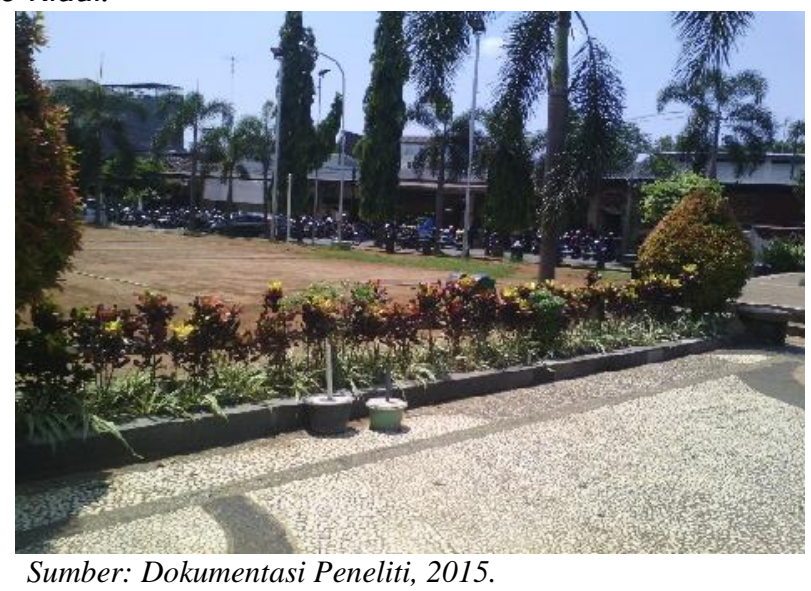

\section{Gambar 4. Fasilitas Rekreasi di Sekitar Kelurahan Muktiharjo Kidul}

Kajian Teori

\section{Kolam Retensi}

Menurut Peraturan Menteri Pekerjaan Umum No. 12 tahun 2004 tentang Penyelenggaraan Sistem Drainase Perkotaan, kolam retensi adalah prasarana drainase yang berfungsi untuk menampung dan meresapkan air hujan di suatu wilayah. Poin utama dari definisi kolam retensi berkaitan dengan fungsinya adalah menampung dan meresapkan. Kedua fungsi tersebut saat ini juga banyak dikenal sebagai drainase yang berwawasan lingkungan karena memberikan kesempatan bagi air untuk menyerap ke tanah. Sebagai lahan resapan, salah satu syarat dari pembangunan kolam retensi adalah penentuan lokasi yang berada pada bagian terendah dari lahan keseluruhan. Secara teknis, untuk membangun sebuah kolam retensi membutuhkan data klimatologi, hidrologi, daerah genangan, faktor penyebab banjir, peta dasar, jaringan jalan, tata guna lahan, peta kawasan permukiman sekitar, topografi, serta data kependudukan.

Komponen-komponen yang harus ada dalam sistem polder meliputi:

1. Tanggul keliling dan/atau pertahanan laut (sea defense) atau konstruksi isolasi lainnya.

2. Sistem drainase lapangan (field drainage system)

3. Sistem Pembawa (conveyance system)

4. Kolam Penampungan dan stasiun pompa (outfall system)

5. Badan air penerima (recipient waters) 
Kelima komponen sistem polder harus direncanakan secara integral, sehingga sistem dapat bekerja secara optimal. Tidak ada artinya membangun sistem drainase lapangan dan outfall yang sempurna dengan kapasitas tinggi, jika saluran pembawa tidak cukup mengalirkan air dari lapangan ke outfall, demikian juga sebaliknya. Terdapat tiga jenis kolam retensi, yaitu kolam retensi disepanjang badan sungai, kolam retensi pada badan sungai, dan kolam retensi storage memanjang

\section{Fasilitas Rekreasi}

Rekreasi berasal dari bahasa latin yaitu "creature" yang berarti mencipta, lalu diberi awalan "re" yang berarti "pemulihan daya cipta atau penyegaran daya cipta". Kegiatan rekreasi biasanya dilakukan di waktu senggang yang bertujuan untuk membentuk, meningkatkan kembali kesegaran fisik, mental, pikiran dan daya rekreasi (baik secara individual maupun secara kelompok) yang hilang akibat aktivitas rutin sehari-hari dengan jalan mencari kesenangan, hiburan dan kesibukan yang berbeda dan dapat memberikan kepuasan dan kegembiraan yang ditujukan bagi kepuasan lahir dan batin manusia (Karyono, 1997).

\section{Kelayakan Ekonomi}

Proyek yang akan dibangun sebelum memulai tahap pembangunan perlu diketahi apakah layak untu dikerjakan. Suatu pendekatan yang digunakan dalam analisis ekonomi dan finansial untuk rekomendasi kebijakan dengan cara membandingkan total biaya (cost) dan total manfaat (benefit) yang disebut dengan analisis biaya manfaat. Analisis biaya manfaat merupakan salah satu kriteria yang harus dipertimbangkan dalam melakukan studi kelayakan proyek investasi. Adapun kriteria lain yang harus dipertimbangkan dalam melakukan studi kelayakan proyek investasi adalah periode pengembalian (Payback Periode). Analisis biaya manfaat dilakukan dengan tiga tahap, yaitu:

1. Menentukan semua manfaat yang timbul dari suatu proyek,

2. Menghitung semua biaya dan manfaat dalam satuan rupiah,

3. Menghitung NPV dan analisis perhitungan BC ratio.

\section{Manajemen Pembangunan}

Manajemen banyak dilakukan pada berbagai bidang ilmu pengetahuan, dengan fokus yang berbeda beda. Secara bahasa, management atau manajemen diartikan sebagai pengelolaan, yang merupakan seperangkat aktivitas (termasuk perencanaan dan penetapan keputusan, penyusunan, dan kontrol) yang ditujukan kepada sumber daya, dapat berupa sumber daya manusia, finansial, fisik, maupun informasi dengan tujuan akhir mencapai tujuan organisasi dengan upaya yang efektif dan efisien. jika dikaitakan dengan fasilitas rekreasi, manajemen pembangunan dilakukan untuk pelaksanaan rencana dari desain yang telah dirancang.

\section{Kerjasama Pemerintah-Swasta}

Menurut Peraturan Presiden No 67 Tahun 2005, proyek kerjasama penyediaan infrastruktur antara pemerintah dengan badan usaha dilakukan dengan tujuan untuk mencukupi kebutuhan pendanaan secara berkelanjutan dalam penyediaan infrastruktur melalui pengerahan dana swasta; meningkatkan kualitas, kuantitas, dan efisiensi pelayanan melalui persaingan sehat; meningkatkan kualitas pengelolan dan pemeliharaan dalam penyediaan infrastruktur; mendorong digunakannya prinsip pengguna membayar pelayanan yang diterima, atau dalam halhal terteneu mempertimbangkan kemampuan membayar pengguna.

Bentuk kerjasama pemerintah dengan swasta salah satunya adalah BOT (build operate transfer) yang karakteristiknya adalah kontrak BOT digunakan dengan melibatkan investasi swasta pada pembangunan konstruksi infrastruktur baru. Biasanya jenis pembangunan berupa infrastruktur baru. Swasta menyediakan modal untuk membangun fasilitas baru, kemudian pemerintah menyetujui untuk mengeluarkan tingkat produksi yang minimum untuk memastikan bahwa operator dapat memenuhi biaya selama operasional. 
Hasil dan Pembahasan

\section{Kebutuhan Fasilitas Rekreasi}

Kolam retensi yang termasuk pada sistem saluran drainase menjadi perhatian dalam mengatasi masalah banjir yang sering terjadi di Kelurahan Muktiharjo Kidul. Adanya kolam retensi seluas $5,4 \mathrm{Ha}$ menjadi salah satu potensi untuk mengembangkan lokasi tersebut sebagai ruang publik yang juga dapat dimanfaatkan sebagai fasilitas rekreasi. Berdasarkan survei yang telah dilakukan didapatkan hasil bahwa mayoritas masyarakat yang berada pada Kelurahan Muktiharjo Kidul merasa bahwa masih belum adanya pemenuhan akan fasilitas rekreasi. Banyak dari masyarakat yang berada di Kelurahan Muktiharjo Kidul yang mencari fasilitas lain menuju ke wilayah lain. Pemenuhan fasilitas rekreasi pada wilayah Kelurahan Muktiharjo Kidul dirasa perlu untuk memberikan ruang bagi masyarakat bersosialisasi dan mengisi kegiatan sehari-hari dengan positif. Penerimaan warga terhadap rencana pembangunan fasilitas rekreasi cukup tinggi karena merupakan hal yang baru di lingkungan tempat tinggalnya. Menurut hasil penyebaran kuesioner didapatkan bahwa 90\% masyarakat setuju dengan adanya pembangunan fasilitas rekreasi pada kolam retensi. Harapannya dengan dibangun fasilitas rekreasi pada kolam retensi dapat menjadi alternatif baru dan lokasi pilihan untuk kegiatas rekreasi.

\section{Strategi Perencanaan}

Strategi yang perlu dilakukan dalam pembangunan kolam retensi ini dapat mengarahakan dalam perencanaan yang dilakukan sehingga tepat sasaran. Strategi yang dilakukan yaitu dengan terpenuhinya kriteria yang digunakan dalam penentuan lokasi kolam retensi pembangunan tersebut sebagai upaya dalam menanggulangi banjir. Pengoperasian dan pengelolaan melibatkan kerjasama antar pemerintah dan masyarakat agar kinerja dari sistem drainase dapat berjalan dengan baik. Diperlukannya peningkatan kesadaran masyarakat untuk mengurangi resiko banjir. Perencanaan kolam retensi sebagai fasilitas rekreasi dapat menimbulkan dampak yang cukup baik bagi masyarakat sekitar. Selain itu juga operasional fasilitas rekreasi merupakan wewenang pemerintah dan dikerjakan oleh masyarakat. Dengan begitu, strategi yang telah dirumuskan dapat membangun masyarakat sekitar dan juga memenuhi kebutuhan dari masyarakat tersebut.

Fasilitas Rekreasi

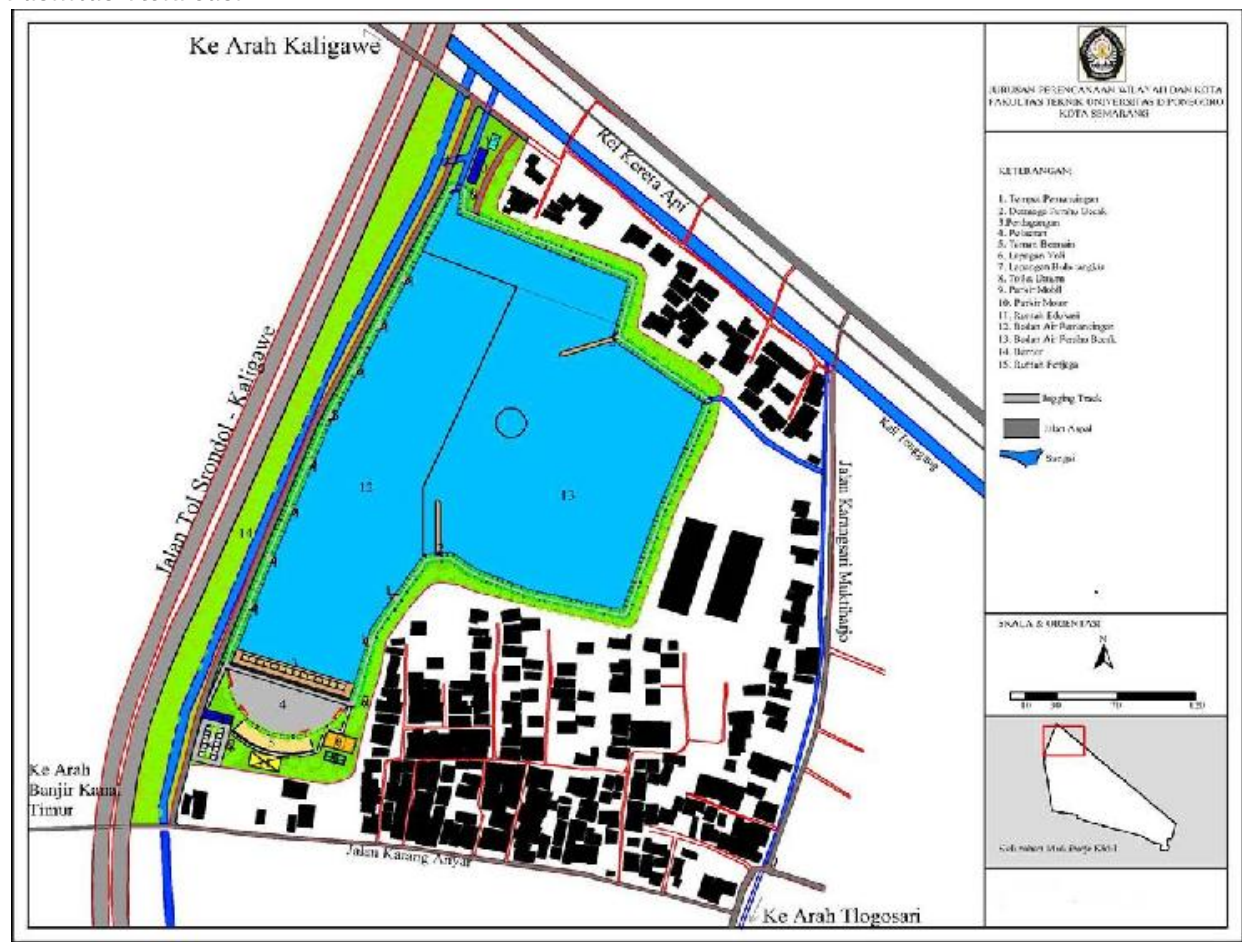

Sumber: Analisis peneiti, 2015.

Gambar 4. Siteplan Fasilitas Rekreasi

DOI: HTTP://DX.DOI.ORG/10.14710/RUANG.1.4.221-230 
Pada gambar diatas, terlihat bentuk dari rencana fasilitas rekreasi yang akan dibangun. Badan kolam tidak digunakan seluruhnya untuk fasilitas rekreasi berupa pemancingan dan permainan air. Selebihnya, fasilitas rekreasi dilakukan pada wilayah daratan disekitar kolam berupa jogging track, taman bermain, rumah edukasi, dan lapangan olahraga. Terdapat dua pintu masuk, yaitu di selatan yang tujuannya untuk mempermudah warga yang ingin berkunjung, dan di utara untuk pengunjung dari luar Kelurahan Muktharjo Kldul. Beberapa aspek pembangunan berkelanjutan yang diterapkan pada fasilitas rekreasi adalah:

* Sosial. Penyediaan fasilitas rekreasi dapat memenuhi kebutuhan masyarakat dalam segi sosialnya karena dapat digunakan sebagai lokasi berkumpul dan lokasi hiburan.

- Lingkungan. Dilakukannya penghijauan disekitar lokasi kolam merupakan salah satu bentuk pelestarian lingkungan dalam menjaga kualitas lingkungan supaya memperbesar jumlah tangkapan dan sebagai penyaring udara dari kepadatan lalu lintas disekitarnya.

- Ekonomi. Operasional dan penyediaan kios pada fasilitas rekreasi membuka lapangan pekerjaan bagi masyarakat sekitar.

Pembiayaan Pembangunan dan Kelayakan Proyek dalam Analisis Finansial

\begin{tabular}{llll}
\hline Total cost & Total benefit & Keuntungan & $\begin{array}{l}\text { Payback } \\
\text { Periode }\end{array}$ \\
\hline Rp 19.317.436.480,00 & Rp 80.608.070.400,00 & Rp 61.290.633.920,00 & $\begin{array}{l}\text { Tahun } \\
\text { ke-4 }\end{array}$ \\
\hline
\end{tabular}

Nilai NPV 24.799.290.601, BCR 3.24, IRR 47\% (Layak)

Pembiayaan Pembangunan dan Kelayakan Proyek dalam Analisis Ekonomi

\begin{tabular}{llll}
\hline Total cost & Total benefit & Keuntungan & $\begin{array}{l}\text { Payback } \\
\text { Periode }\end{array}$ \\
\hline Rp 2.071.904.000,00 & Rp 4.344.820.152,00 & Rp 2.272.916.152,00 & $\begin{array}{l}\text { Tahun } \\
\text { ke-4 }\end{array}$ \\
\hline
\end{tabular}

Nilai NPV 301.278.850, BCR 1, IRR 10\% (Layak)

\section{Konsep Kerjasama Build Operate Transfer (BOT)}

Penentuan konsep pengembangan fasilitas rekreasi pada kolam retensi dilakukan dengan sistem BOT. Alasan pemilihan konsep BOT antara lain kekurangan dana pemerintah dan pendekatan yang dinamakan sebagai handsoff approach dari pemerintah. Sehingga dengan BOT dapat mengurangi beban penggunaan dana APBN/APBD atau pinjaman luar negeri. Selain itu alasan yang lain yaitu kurangnya sumber daya manusia sehingga proses pembangunan sebuah usaha/fasilitas yang layak operasi dan profitable yang hanya bisa dilaksanakan oleh pihak swasta yang kompeten di bidangnya. Dengan BOT, sektor swasta berperan dalam hal mendesain, menyediakan keuangan, membangun dan mengoperasikan fasilitas untuk kemudian akhirnya setelah masa tersebut berakhir maka kepemilikan akan kembali ditransfer kepada pemerintah. Struktur pembiayaan yang diterapkan pada konsep BOT pada kawasan perancangan ini yaitu pihak swasta berperan untuk menyediakan modal untuk membangun fasilitas baru. Sedangkan pemerintah akan menyetujui untuk mengeluarkan tingkat produksi yang minimum untuk memastikan bahwa operator swasta dapat menutupi biayanya selama pengoperasian

Berakhirnya keterlibatan sektor swasta dalam pembangunan kawasan fasilitas rekreasi dan operasional terjadi pada pengembalian kepemilikan fasilitas kepada pemerintah setelah masa 20 tahun. Dalam pendekatan BOT yang diterapkan di kawasan perancangan, pihak swasta mempertahankan suatu isi kontrak dalam periode yang disepakati, untuk pengembangan dan pelaksanaan pembangunan fasilitas, pembangunan mana yang terdiri dari pembiayaan, desain, konstruksi, mengelola dan memelihara fasilitas, dan membuat fasilitas tersebut menguntungkan. Karakteristik terpenting dari BOT di kawasan perancangan ini adalah pendanaan dari swasta. Dalam BOT, pemerintah mensubkontrakkan seluruh proses pembangunan, termasuk risiko yang terkait kepada entitas swasta. Salah satu resiko 


\section{Kesimpulan dan} Rekomendasi ini adalah pembiayaan, yang harus diperoleh oleh pemegang konsesi yaitu pihak swasta, yang pada bertanggungjawab kepada semua aspek proyek.

Keuntungan bagi pemilik proyek (pemerintah) adalah dapat mengurangi beban penggunaan dana APBN/APBD atau pinjaman luar negeri, konsep BOT juga secara financial menguntungkan karena tidak perlu mengeluarkan biaya untuk melakukan studi kelayakan dan biaya oprasional dan pemilik proyek juga tidak menanggung resiko dalam perubahan nilai kurs. Kemudian keuntungan bagi pelaksana proyek (swasta) dapat melakukan ekpansi usaha yang mempunyai prospek menguntungkan serta dapat memanfaatkan lahan strategis yang dimilki pemilik proyek (pemerintah) disisi lain saat proses pembangunan kawasan industri ini untuk beberapa fasilitas dapat melakukan kerjasama dengan beberapa pemerintah, sehingga pada saat pembiayaan bisa meminimkan pengeluaran dari pihak pelaksana proyek (swasta). Keuntungan dalam konsep BOT untuk pelaksana proyek juga dapat meningkatkan profesionalisme dan meningkatkan daya saing perbangkan. Sedangkan untuk masyarakat dengan adanya peran swasta dalam pengelolaan makan masyarakat lebih terjamin dengan kualitas pelayananya. Swasta ingin menanamkan investasi pada kawasan industri terletak di pengelolaan infrastruktur yang ada.

Dalam konsep BOT ini pada akhirnya semua keuntungan dari operasional kawasan perancangan ini tidak hanya untuk pihak swasta, tapi nantinya akan ada sistem pembagi hasil baik dari pihak pemerintah, swasta dan masyarakat lokal juga. Dengan pola kemitraan ini diharapkan pemerintah dapat menghemat pengeluaran dalam hal pembiayaan pembangunan serta tetap mendapatkan keutungan dari hasil pengelolaan kawasan fasilitas rekreasi. Kawasan fasilitas rekreasi ini dibangun untuk memenuhi kebutuhan masyarakat setempat akan fasilitas rekreasi. Dengan adanya fasilitas rekreasi pada kolam retensi dapat meningkatkan fungsi dari kawasan di sekitarnya. Melalui konsep BOT ini diharapkan mampu mengembangkan fasilitas rekreasi pada kolam retensi sehingga antara aktivitas rekreasi dan fungsi dari kolam retensi itu sendiri sebagai bangunan pengendali banjir dapat berjalan secara optimal dan berdampingan.

\section{Kesimpulan}

Perencanaan fasilitas rekreasi dimulai dengan penentuan jenis yang akan dibangun berdasarkan karakteristik wilayah, ketentuan standar, dan preferensi masyarakat. Setelah mengetahui jenis fasilitas rekreasi yang akan dibangun, dilakukan perancangan untuk mengetahui desain fasilitas rekreasi. Kemudian untuk menerapkan desain tersebut dilakukan analisis kelayakan dan perhitungan biaya dari pembangunan yang akan dilakukan. Ketiga tahapan tersebut telah dilakukan, yang hasilnya adalah:

a. Jenis fasilitas rekreasi yang akan dibangun adalah taman kota dengan atraksi berupa permainan air, pemancingan, lapangan olahraga, rumah edukasi, jogging track, dan taman bermain.

b. Perancangan fasilitas rekreasi dilakukan pada $48.110 \mathrm{~m}^{2}$ badan kolam dan $16.718 \mathrm{~m}^{2}$ daratan disekitarnya dengan luas total $64.828 \mathrm{~m}^{2}$. Pekerjaan pembangunan fasilitas rekreasi pada tahap pra konstruksi dan konstruksi dilakukan selama 2 tahun 6 bulan pada tahun 2016 dan operasional akan dilakukan selama kurang leih 16 tahun.

c. Manajemen pembangunan fasilitas rekreasi dilakukan dengan mengetahui jumlah prakiraan pembiayaan pembangunan. Pada analisis finansial total cost yang dibutuhkan adalah Rp 19.317.436.480,00 selama 20 tahun dengan jumlah benefit sebanyak Rp 80.607.070.400,00. Payback periode terjadi pada tahun ke 4 dengan nilai NPV 24.799.290.601, nilai BCR 3,24, nilai IRR 47\% yang dapat dinyatakan layak. Pada analisis ekonomi, total cost yang dibutuhkan adalah Rp 2.071.904.000 dengan jumlah benefit Rp 4.344.820.152 dengan nilai NPV 301.278.859, nilai BCR 1, dan nilai IRR 10\%. Pada analisis ekonomi, pembangunan fasilitas rekreasi juga dinyatakan layak

Pembangunan kolam retensi akan dilakukan dengan sistem kerjasama pemerintah-swasta BOT (build operate transfer) dengan pertimbangan keterbatasan dana dari pemerintah, bagi hasil selama masa konstrak, dan kepemilikan fasilitas rekreasi pada akhir masa kontrak. Selama 20 tahun usia proyek, pemerintah tidak 
mengambil banyak peran dalam pembangunan fasilitas rekreasi karena telah diambil alih oleh swasta. Peran pemerintah adalah pada monitoring supaya pembangunan dapat berjalan sesuai dengan time schedule yang telah ditetapkan. Waktu kontrak selama 20 tahun dianggap telah mampu memberikan keuntungan bagi pihak swasta serta bagi pemerintah yang selanjutnya berperan sebagai pemegang kuasa.

\section{Rekomendasi}

Bagi pemerintah, rekomendasi yang akan diberikan adalah berupa perencanaan fasilitas rekreasi yang lengkap mulai dari penentuan jenis fasilitas rekreasi, desain perancangan, serta pembiayaannya yang berfungsi dalam rencana pembangunan fasilitas rekreasi oleh pemerintah yang belum dilaksanakan. Kerjasama dengan sistem BOT dapat digunakan untuk pembangunan fasilitas rekreasi dengan masa kontrak selama 20 tahun. Pembangunan kolam retensi diharapkan dapat cepat selesai supaya berfungsi dengan maksimal dalam menampung air dan mengendalikan banjir. Pemerintah perlu untuk meningkatkan kesadaran masyarakat untuk tidak merusak semua kelengkapan bangunan fasilitas rekreasi maupun kolam retensi supaya dapat terus beroperasi dengan maksimal serta melakukan kerjasama dengan masyarakat dalam pemeliharaan fasilitas rekreasi, salah satunya dengan mengadakan acara-acara di fasilitas rekreasi.

Bagi masyarakat, rekomendasi yang akan diberikan adalah perlu meningkatkan kesadaran diri sendiri maupun keluarga dan lingkungan terdekat untuk menjaga lingkungan dengan mengubah perilaku yang merusak alam seperti membuang sampah sembarangan dan penebangan pohon untuk dibangun rumah karena berpengruh terhadap lingkungan yang cakupannya lebih luas lagi. Masyarakat juga dapat mulai merubah pola pemikirannya untuk lebih demokratis, kritis dan madani supaya tidak bersifat apatis dengan menolak segala pembangunan yang dilakukan pemerintah. Pembangunan pasti akan menimbulkan dampak negatif dan positif namun dengan perencanaan yang tepat dampat negatif dapat diketahui solusinya dan dampat positif dapat dipertahankan.

\section{Daftar Pustaka}

Budimanta, A. 2005. Memberlanjutkan Pembangunan di Perkotaan Melalui Pembangunan Berkelanjutan dalam Bunga Rampai Pembangunan Kota Indonesia dalam Abad 2l. Jakarta: Gramedia Pustaka Utama.

Dinas Pengelolaan Sumber Daya Air Kota Semarang. 2014. Laporan Nota Desain Pembangunan Kolam Retensi Muktiharjo Kidul.

Hindarko, S. 2000. Drainase Perkotaan. Jakarta: Esha.

Karyono, H. 1997. Kepariwisataan. Jakarta: Gramedia Widia Sarana Indonesia.

Kodoatie, R.J. 2003. Pengantar Manajemen Infrastruktur. Semarang: Pustaka Pelajar.

Peraturan Walikota Semarang No. 17 Tahun 2013 Tentang Rencana Kerja Pembangunan Daerah (RKPD) Kota Semarang Tahun 2014.

Sugiyono, 2009. Metode Penelitian Kuantitatif, Kualitatif dan R\&D. Bandung: Alfabeta.

Suripin. 2004. Sistem Drainase Perkotaan yang Berkelanjutan. Yogyakarta: Andi.

Terry, G. R. 2000. Prinsip-prinsip Manajemen. Bandung: PT Bumi Aksara.

Peraturan Menteri Pekerjaan Umum No 12 Tahun 2004 Tentang Penyelenggaraan Sistem Drainase Perkotaan.

Undang-Undang Nomor 26 Tahun 2007 Tentang Penataan Ruang.

Yunus, H.S. 2010. Metodologi Penelitian Wilayah Kontemprorer. Yogyakarta: Pustaka Pelajar. 